\title{
Sap Flow Dynamics and Responses to Grazing and Seasonal Changes in Soil Moisture for Acacia Ancistroclada and Comberatum Molle in a Kenyan Savanna
}

Joseph Ondier ( $\square$ josephondier@yahoo.com )

Maseno University School of Biological and Physical Science https://orcid.org/0000-0002-0858-574X

Dennis Otieno

Jaramogi Oginga Odinga University of Science and Technology School of Biological and Physical

Sciences

\section{Daniel Okach}

Universitat Bayreuth

John Onyango

Maseno University School of Biological and Physical Science

\section{Research}

Keywords: sap flow, trees, grazing, savanna

Posted Date: August 7th, 2020

DOI: https://doi.org/10.21203/rs.3.rs-48464/v1

License: (c) (i) This work is licensed under a Creative Commons Attribution 4.0 International License.

Read Full License 


\section{Abstract}

The Kenyan savanna, which is dominated by Acacia ancistroclada and Comberatum molle, has experienced notable changes in rainfall patterns and increased livestock grazing. A significant decrease in trees spread from $5 \%$ to less than $1 \%$ has been documented for the ecosystem and could be linked to the increased livestock grazing and changes in rainfall patterns, however, scientific evidence is lacking. We utilized sap flow to analyze the hydraulic responses of the prevailing trees to livestock grazing and seasonal changes in soil moisture. Environmental factors including precipitation, air temperature, soil moisture at $-0.3 \mathrm{~m}$, and vapor pressure deficit were simultaneously measured. The results showed that the diurnal variation in sap flux density exhibited a single peak curve at around midday and correlated strongly with vapor pressure deficit and air temperature. Sap flux density was higher in the grazed $(27.47 \pm 8.65 \mathrm{~g}$ $\left.\mathrm{m}^{-2} \mathrm{~s}^{-1}\right)$ than the fenced plots $\left(20.17 \pm 7.27 \mathrm{~g} \mathrm{~m}^{-2} \mathrm{~s}^{-1}\right)$. In all the plots, sap flux density followed seasonality in rainfall patterns, increasing and decreasing in wet and dry seasons respectively. The higher crown projected area was responsible for higher sap flow in the grazed plots. The diurnal variation in sap flux density showed that sap flow was coupled to the atmosphere with relatively low boundary layer resistance and the seasonal variation in sap flow was controlled by stomatal regulation. These findings point to the possibility that the dominant tree species in Lambwe are isohydric species. However, additional measurements need to be conducted on the eligibility of the species to confirm the conclusion.

\section{Introduction}

The structure and function of savannas, especially in Africa are undergoing modification which may be attributed to climate change and land use (Hill and Southworth, 2016; Sankaran, 2019). In most of these regions, the rainy seasons have become shorter while droughts have become more frequent (Sillman et al., 2013; Sankaran, 2019). Livestock numbers have risen and led to increased grazing and alteration of vegetation functions (EKgosikoma et al., 2015; Ondier et al., 2019). An understanding of the mechanisms that underlie plant responses to the increased livestock grazing and altered rainfall patterns is important in comprehending how the ecosystems would respond to the environmental changes. Such information would be useful in the conservation of savannas and other comparable ecosystems.

The increase in livestock grazing and changing rainfall patterns is negatively impacting vegetation physiological processes such as water transport and carbon assimilation (Baudena et al., 2015). The tree component of savannas which has a significant contribution to the ecosystems' hydrological balance is severely impacted under such environmental changes (Wu et al., 2017). Some tree species may adjust physiologically and survive under the ecological change processes (Wang et al., 2010). However, the resistance to the ecological adjustments may be dependent upon the intensity and length of the change process and the versatility of the species considered (Wang et al., 2010; Midgley et al., 2010a and b).

The sap flow mechanism, an important tool in investigating the movement of water in the stem of plants can mirror the physiological attributes and transpiring responses of trees to environmental factors (Mapeto et al., 2018). Some studies have reported increased tree sap flow with increasing soil moisture levels (Zepp et al., 2007; Eliades et al., 2018) whereas others have revealed contradictory results (O'Grady 
et al., 1998; Plaut et al., 2013). The influence of soil moisture on sap flow may be related to multiple factors such as tree species (Cheng et al., 2006), rainfall amount and other environmental factors (Ivans et al., 2006). For example, deep rooted Australian Eucalyptus miniata and Eucalyptus tetrodonta exhibited increased sap flow during the dry seasons compared to the wet season and this was linked to increased evaporative demand and exploitation of the belowground water aquifers by the tree roots (O'Grady et al., 1998). On the other hand, shallow rooted Isopogon gardneri exhibited increased sap flow in response to improved moisture levels in Southern Australia (Burgess, 2006), a tendency which was linked to efficient use of available soil moisture. Trees with broad leaves show the greatest increase in sap flow with increasing vapor pressure deficit, while the narrow leaved show the lowest sap flow (Komatsu et al., 2007). Leaf area and stomatal regulation may account for the varying behavior in response to the changes in environmental and water conditions (Solari et al., 2006; Rodriguez-Gamir et al., 2016).

Based on the stomatal regulation of sap flow, savanna trees may be categorized as either isohydric or anisohydric species (Roman et al., 2015; Zhang et al., 2017). Isohydric species reduce stomatal conductance and sap flow as soil water decreases, hence maintaining constant leaf water potential (Roman et al., 2015). However, a consequence of this strategy is that the trees shut their stomata in response to even mild water stress, a process which though reduces tree water loss, often results in carbon starvation (Cheng, et al., 2014; Sankaran, 2019). In contrast, anisohydric species allow large fluctuations in leaf water potential, maintaining high stomatal conductance and sap flow even during periods of water stress (Kinings and Gentine, 2017). This strategy incurs a risk of xylem cavitation, which could ultimately lead to a decline in leaf water supply and tree mortality (McDowell et al., 2008; Yoshimwa et al., 2013).

Savannah trees have evolved with grazing, predominantly by wild herbivores, that normally occur at an ecologically sustainable level (Kioko and Seno, 2012; Mureithi et al., 2014; Mojeremane, 2015). However, with expanding livestock numbers, the ecosystems have experienced increased grazing pressure, which likely influences soil water infiltration and tree water transport (Sankaran 2019). At high grazing intensities and on steep slopes, prolonged trampling by grazers may result in surface runoffs and reduced soil water infiltration (DeLonge and Basche, 2018), thus reducing the water reaching the root zones of trees. Such conditions induce tree water stress and result in reduced sap flow and increased tree mortalities. Nevertheless, most savanna tree species have well developed deep rooting systems that access below ground water reservoirs (Miller et al., 2010) and can, therefore, overcome the induced water stress. Alternatively, grazing may increase the availability of soil water by reducing competition from the herbaceous layer, as suggested by models of savanna tree-grass coexistence (Sankaran et al., 2004; Baudena et al., 2010). In such scenarios, grazing would, therefore, contribute to the maintenance of water transport in savannah trees.

The Kenyan savanna located in Lambwe Valley has experienced significant changes in rainfall patterns and land use over the years (Njoka et al., 2003; Muriuki et al., 2005). The ecosystem has witnessed increased livestock grazing, increased drought periods, and short episodes of intense rainfall (Otieno et al., 2011; Ondier et al., 2019). The changing rainfall patterns might be modifying soil moisture levels with implications on tree survival and water transport. Reports of declining forest cover from $5 \%$ to less than 
1\%, documented for the region (Njoka et al., 2003; Scharsich et al., 2019), could be linked to the changing environmental factors, however, scientific evidence is lacking. This study used sap flow to investigate the responses of dominant tree species to the increased livestock grazing and seasonal changes in soil moisture. The understanding of water use strategies of the savanna trees under the environmental change scenario will help in decision making aimed at conserving the savannah and other similar ecosystems.

\section{Materials And Methods}

\section{Study site}

The experiment was conducted in Ruma, Lambwe valley $\left(00^{\circ} 35^{\prime} \mathrm{S} \& 34^{\circ} 12^{\prime} \mathrm{E}\right)$. The valley which sits inside a humid savanna in western Kenya has an elevation of around $1300 \mathrm{~m}$ above sea level.

Surrounding the valley are Gembe and Gwassi hills located to the west and Kanyamwa escarpment to the East. The average yearly rainfall of the location is $1100 \mathrm{~mm}$ and occurs in a bimodal pattern between April-June and September-December (Fig. 1). The environment is warm and humid with a yearly average air temperature of $22^{\circ} \mathrm{C}$. Other than the broad savanna with semi-natural vegetation, other land use types include a protected area under the Ruma National Park, human settlements, and open cattle (cows, sheep, and goats) grazing fields with animal stocking rate of 7.4 animal units ha ${ }^{-1}$ (Ondier et al., 2019). The soils at the valley base are black clays and are plentiful in minerals (Allsopp and Baldry1972). The higher elevations are covered with trees, while the sloppy grounds are dominated by herbaceous vegetation. Measurements were conducted on a slightly sloping area (slope $\left.=3^{\circ}\right), 150$ ha terrain mainly open woodland and thickets dominated by tree genera of Acaciaancistroclada and Combretum molle, and a wide diversity of herbaceous vegetation, dominated by the grass species Hyparrhenia filipendula. The experimental site had tree canopy cover of approximately $20 \%$.

\section{Microclimate}

Between January 2014 and December 2015, an automatic microclimate station (AWS-WS-GP1, Delta-T Devices, Cambridge, UK) installed in an open place within the study area, was used to measure rainfall and air temperature $\left(T_{\text {air }}\right)$. Data were taken each 5 minutes, averaged and logged after every 30 minutes. Air humidity and air temperature were measured using FUNKY-Clima, (ESYS, Berlin, Germany), and soil temperature at $-30 \mathrm{~cm}$ (HOBO- ware, SynoTech, Linnich, Germany) were measured every $5 \mathrm{~min}$, and data were averaged and logged half- hourly.

\section{Sap flow measurements in trees}

On the hill slope dominated by trees, grazed and fenced plots measuring $70 \mathrm{~m}$ by $50 \mathrm{~m}$ were randomly established at $100 \mathrm{~m}$ apart and each replicated three times. Fenced plots were set up by erecting $2 \mathrm{~m}$ high perimeter fence to exclude livestock whereas grazed plots were open savannas subjected to livestock grazing. A minimum of 3 individual dominant trees species (Combretum molle and Acacia ancistroclada) were utilized for estimation of sap flux density SFD $\left(\mathrm{g} \mathrm{m}^{-2} \mathrm{~s}^{-1}\right)$ using uniquely designed, heat dissemination tests developed after Granier's (1987) design. Each sensor consisted of a pair of thermistor of 2-mm- 
diameter which was vertically aligned ca. $10 \mathrm{~cm}$ apart. The two thermocouples were joined at the constantan leads, so that the voltage measured across copper leads provided the temperature difference between the heated probe and the lower reference. The data loggers and the sensors were powered by 120 mA storage cells (Grainer 1987).

Sensors were placed in the outer $20 \mathrm{~mm}$ of the sap wood (annulus, 1, 0-20 mm radial sapwood depth). In cases where the tree trunk were large with sapwood radius greater than $20 \mathrm{~mm}$, a second sensor was placed 10-15 cm circumferentially, away from the first sensor pair, on the same side of the stem to avoid azimuth differences. Temperature differences were measured every 5 minutes and 30 minutes mean value logged (DL2e with LAC-1 in single ended mode, Delta-T Devices, England). Sap flux density (SFD, $\mathrm{g} \mathrm{m}^{-2} \mathrm{~s}^{-1}$ ) for every sensor was determined from $\mathrm{DT}$ in accordance with Grainer (1987) assuming zero SFD (i.e. $\square T_{\text {max }}$ ) at night and VPD close to zero:

$\mathrm{SFD}=119 \mathrm{~K}^{1.231}$ .eq. 1

Where,

$\mathrm{K}=\underline{\square \mathrm{Tax}} \underline{\underline{\operatorname{ma}}}$ eq 2

$\square T$

\section{Tree allometrics}

The sample trees were selected according to species and tree size distribution within the experimental plots. To estimate the sap wood area (SA) of the sample trees, an increment borer was used to extract cores of sapwood at the sensor installation height (about $1.5 \mathrm{~m}$ height) on the same species, but different trees from those installed with sap flow sensors. The depth of the sap wood depth was visually determined at those cores, as wood and heartwood were clearly different. Sap wood area was determined from sapwood depth and tree DBH based on equation (Vertessy et al., 1995; Meinzer et al., 2005):

$\mathrm{SA}=\mathrm{a} \times \mathrm{DBH}^{\beta}$. eq. 3

Where $\alpha$ is a constant and $\beta$ is allometric scaling exponent, and both are species-specific coefficients.

The ground projected crown area $\left(\mathrm{m}^{2}\right)$ of sample trees was measured in eight horizontal directions using compass, crown mirror and a measuring tape. The octagonal area was determined as the whole of eight triangles (Schmidt, 2007).

\section{Soil water content}

Within the grazed and fenced plots, continuous SWC in the upper 30-cm soil layer was monitored using Theta probes (type ML 2X, Delta-T Devices, Cambridge, UK). Data were collected every 30 min, averaged, and logged hourly using a data logger (DL 2e-Delta-T Devices, Cam- bridge, UK).

\section{Analysis of Plant Root Distribution}


Analysis of plant root distribution was done by excavating the selected soil profiles down to a depth of about $1 \mathrm{~m}$ or a depth where concrete rock material was found. Soil profiles $(\sim 0.5 \times 1 \mathrm{~m})$ down to a depth of consolidated rock material were dug within grazed and fenced plots at locations under the tree canopies. Each profile was divided into individual soil horizons and subsequently analyzed for depth distributions of roots. Coarse ( $>2 \mathrm{~mm}$ diameter) and fine ( $<2 \mathrm{~mm}$ diameter) root densities for each horizon were determined by counting all roots and dividing the number by the area of the profile wall covered by the associated horizon.

\section{Stomatal conductance}

Monthly measurements of diurnal courses of stomatal conductance was carried out using steady state porometer, model LI-1600, LI COR, USA; with a cuvette for attaching the studied leaves. On each measurement day, three different trees of the same species were selected for measurement. Well exposed leaves were identified from each of the tree, and measurements conducted on the same leaves between 08:00 and 17:00 local time to avoid wet canopy conditions caused by morning and late evening dew (leading to high values of $g_{s}$ ). Tree crowns were accessed using a $3 \mathrm{~m}$ high ladder. Care was taken not to damage the leaves during measurements by using a soft air tight pad placed over the mouth of the cuvette. Each leaf was mounted in the cuvette so that it received full illumination during measurement. Every turn of measurement lasted one to two minutes to allow the chamber to equilibrate. Alternate measurements were conducted between species throughout the day.

\section{Statistical analysis}

SFD and environmental variables were recorded as half hourly average values. These variables, including Gc were converted into daily and monthly averages. Data are presented as mean \pm standard deviation

(SD). SFD, $T_{\text {air }}$ VPD and Gc were compared between grazed and fenced plots, within months and among tree species using one way anova. Where differences were found among species, a post hoc test was carried out. All statistical analysis were based on 0.05 significance level and performed with SAS version 9.1 (California, USA).

\section{Results}

\section{Microclimate of the study site}

The total rainfall amount in 2014 and 2015 were $1148.4 \mathrm{~mm}$ and $1169.5 \mathrm{~mm}$ respectively. Rainfall was bimodal, occurring in April to June and September to December. On average, monthly air temperature was $22.95 \pm 4{ }^{\circ} \mathrm{C}$ and $22.35 \pm 3.2{ }^{\circ} \mathrm{C}$ in 2014 and 2015 respectively. The hottest month was February while the coldest month was July (Fig. 1).

\section{Soil water content within Grazed and Fenced plots}

In all the plots, soil water content followed seasonality in rainfall pattern, increasing and decreasing during wet and dry seasons respectively. April- June and September-December were wet periods while January- 
March and July and August were dry periods (Fig.2).

\section{Root distribution patterns}

The depth of soil on which our plots were established ranged between 50 and $70 \mathrm{~cm}$ below which there was a strong presence of course rock fragments. Root distribution patterns were not different between the two locations (Fig). In all the plots, the densities of fine roots were highest at around $20 \mathrm{~cm}$ depth, most of which belonged to grass. Between 30 and $70 \mathrm{~cm}$ depths, coarse roots belonging to trees significantly increased.

\section{Characteristics of the studied trees}

Table 1 shows the morphological characteristics of the selected trees for sap flow measurements and their mean Sap Flux Densities. Mean sup flux density (SFD) between grazed and fenced plots were statistically different $(p<0.0001, f=5.83)$ with grazed plots recording higher SFD $\left(27.02 \pm 8.63 \mathrm{~g} / \mathrm{m}^{2} / \mathrm{s}\right)$ than fenced plots $\left(20.17 \pm 7.27 \mathrm{~g} / \mathrm{m}^{2} / \mathrm{s}\right)$. As SFD is related to $\mathrm{DBH}$, wood area, and crown projected area (Liu et al., 2008; Sevanto et al., 2008), we also determined coefficients between SFD with DBH, wood area and crown projected area from table 1 . The statistically significant $r$ and $p$ values were determined with $r^{2}=0.60, P<$ $0.0001 ; r^{2}=0.61, P<0.0001$ and $r^{2}=0.40, P=0.0022$ respectively. The coefficient of determination between SFD and tree height $\left(r^{2}=0.058, P=0.2912\right)$ was statistically insignificant.

Table 1. Studied sample trees in Lambwe between January 2014 and December 2015 


\begin{tabular}{|c|c|c|c|c|c|c|c|c|}
\hline & $\begin{array}{l}\text { Tree } \\
\text { code }\end{array}$ & Tree name & $\begin{array}{l}D B H \\
(\mathrm{~cm})\end{array}$ & $\begin{array}{l}\text { Wood } \\
\text { area } \\
\left(\mathrm{cm}^{2}\right)\end{array}$ & $\begin{array}{l}\text { wood } \\
\text { area } \\
(m 2)\end{array}$ & $\begin{array}{l}\text { Tree } \\
\text { height } \\
\text { (m) }\end{array}$ & $\begin{array}{l}\text { Crown } \\
\text { projected } \\
\text { area } \\
(m 2)\end{array}$ & $\begin{array}{l}\text { Mean sap } \\
\text { flux } \\
\text { density } \\
\left(\mathrm{g} / \mathrm{m}^{2} / \mathrm{s}\right)\end{array}$ \\
\hline \multirow[t]{10}{*}{$\begin{array}{l}\text { Grazed } \\
\text { plot }\end{array}$} & $\mathrm{Cm} 1 \mathrm{H}$ & $\begin{array}{l}\text { Comberatum } \\
\text { molle }\end{array}$ & 16.4 & 97.97 & 0.009797 & 4.43 & 17.64 & $15.27 \pm 1.23$ \\
\hline & $\mathrm{Cm} 3 \mathrm{H}$ & $\begin{array}{l}\text { Comberatum } \\
\text { molle }\end{array}$ & 15 & 84.41 & 0.008441 & 6.4 & 12.43 & $16.47 \pm 0.97$ \\
\hline & $\mathrm{Cm} 4 \mathrm{H}$ & $\begin{array}{l}\text { Comberatum } \\
\text { molle }\end{array}$ & 13.3 & 67.94 & 0.006794 & 11 & 20.9 & $7.96 \pm 1.05$ \\
\hline & $\mathrm{Cm} 5 \mathrm{H}$ & $\begin{array}{l}\text { Comberatum } \\
\text { molle }\end{array}$ & 17 & 103.78 & 0.010378 & 5.28 & 19.78 & $28.09 \pm 6.02$ \\
\hline & $\mathrm{Cm} 6 \mathrm{H}$ & $\begin{array}{l}\text { Comberatum } \\
\text { molle }\end{array}$ & 11.9 & 54.38 & 0.005438 & 5.51 & 4.08 & $10.45 \pm 2$ \\
\hline & $\mathrm{Ae} 1 \mathrm{aH}$ & $\begin{array}{l}\text { Acacia } \\
\text { ancistroclada }\end{array}$ & 27.4 & 204.53 & 0.020453 & 5.45 & 58.6 & $25.27 \pm 0.78$ \\
\hline & $\mathrm{Ae} 1 \mathrm{bH}$ & $\begin{array}{l}\text { Acacia } \\
\text { ancistroclada }\end{array}$ & 27.4 & 204.53 & 0.020453 & 5.45 & 58.6 & $23.19 \pm 0.89$ \\
\hline & $\mathrm{Ae} 2 \mathrm{H}$ & $\begin{array}{l}\text { Acacia } \\
\text { ancistroclada }\end{array}$ & 16.2 & 96.03 & 0.009603 & 4.4 & 30.96 & $15.91 \pm 2$ \\
\hline & $\mathrm{Ae} 3 \mathrm{H}$ & $\begin{array}{l}\text { Acacia } \\
\text { ancistroclada }\end{array}$ & 13.3 & 67.94 & 0.006794 & 3.88 & 22.55 & $10.05 \pm 0.73$ \\
\hline & & & & & & & & $\begin{array}{l}\text { Mean } \\
27.02 \pm \\
0.71\end{array}$ \\
\hline \multirow[t]{8}{*}{$\begin{array}{l}\text { Fenced } \\
\text { plot }\end{array}$} & Ae1F & $\begin{array}{l}\text { Acacia } \\
\text { ancistroclada }\end{array}$ & 34.5 & 273.3 & 0.02733 & 10 & 56.7 & $27.04 \pm 2.88$ \\
\hline & $\mathrm{Ae} 2 \mathrm{~F}$ & $\begin{array}{l}\text { Acacia } \\
\text { ancistroclada }\end{array}$ & 20 & 132.84 & 0.013284 & 6.9 & 30.03 & $18.34 \pm 2.14$ \\
\hline & $\mathrm{Ae} 3 \mathrm{aF}$ & $\begin{array}{l}\text { Acacia } \\
\text { ancistroclada }\end{array}$ & 17.4 & 107.66 & 0.010766 & 7 & 55.6 & $15.24 \pm 5.75$ \\
\hline & $\mathrm{Ae} 3 \mathrm{bF}$ & $\begin{array}{l}\text { Acacia } \\
\text { ancistroclada }\end{array}$ & 25 & 181.28 & 0.018128 & 7.3 & 69.66 & $31.21 \pm 3.15$ \\
\hline & $\mathrm{Cm} 2 \mathrm{~F}$ & $\begin{array}{l}\text { Comberatum } \\
\text { molle }\end{array}$ & 23.1 & 162.87 & 0.016287 & 10.3 & 33.37 & $25.96 \pm 7.16$ \\
\hline & $\mathrm{Cm} 3 \mathrm{~F}$ & $\begin{array}{l}\text { Comberatum } \\
\text { molle }\end{array}$ & 15.5 & 89.25 & 0.008925 & 7 & 20.1 & $16.16 \pm 0.82$ \\
\hline & $\mathrm{Cm} 4 \mathrm{~F}$ & $\begin{array}{l}\text { Comberatum } \\
\text { molle }\end{array}$ & 12.4 & 59.23 & 0.005923 & 6.2 & 29.21 & $19.73 \pm 3.41$ \\
\hline & $\mathrm{Cm} 5 \mathrm{~F}$ & $\begin{array}{l}\text { Comberatum } \\
\text { molle }\end{array}$ & 13 & 65.04 & 0.006504 & 9 & 13.58 & $16.03 \pm 1.42$ \\
\hline
\end{tabular}




$\begin{array}{lllllll}\text { Cm6F } \begin{array}{l}\text { Comberatum } \\ \text { molle }\end{array} & 10.7 & 42.76 & 0.004276 & 6.01 & 48.99 & 11.84 \pm 0.1 \\ & & & & & & \text { Mean } \\ & & & & & \mathbf{2 0 . 1 7 \pm} \\ & & & & & \\ & & & & & \end{array}$

\section{Seasonal relationship of sap flow}

Figures 4 show monthly means of sap flow (Kg/hr) among tree species in grazed (A) and fenced (B) plots respectively. Sap flow increased between April and June and September and December. Moreover, sap flow decreased between January and March. The monthly increase and decrease of sap flow coincided with wet and dry seasons respectively

\section{Relationship between sap flow and soil water content}

Figure 5 shows the relationship between sap flow and soil water content measured within $0.3 \mathrm{~m}$ soil profile. There were weak positive correlation between sap flow and soil water content in the grazed (Acacia $r^{2}=0.34$, Comberatum $\left.r^{2}=0.16\right)$ and fenced plots (Acacia $r^{2}=0.12$, Comberatum $\left.r^{2}=0.07\right)$. In all the plots, Acacia ancistroclada recorded lower $(\mathrm{p}<0.05)$ sap flux than Comberatum molle.

\section{Diurnal relationship of sap flux density in response to $T_{\text {air }}$ and vpd}

The diurnal pattern of sap flux density (sfd) on a representative day within grazed and fenced plots display typical diurnal patterns with maximum values occurring around noon. There was a linear relationship between sfd of different tree species and air temperature in both grazed (Acacia $r^{2}=0.70$ and Comberatum $r^{2}=0.71$ ) and fenced plots (Acacia $r^{2}=0.67$, Comberatum $r^{2}=0.68$ ). there was a linear relationship between sfd and vpd in both grazed (Acacia $r^{2}=0.77$ and Comberatum $r^{2}=0.76$ ) and fenced plots (Acacia $r^{2}=0.78$ and Comberatum $r^{2}=0.75$ ). In all the plots, Acacia species recorded significantly $(P<0.05)$ lower sfd in comparison to Comberatum species.

\section{Stomatal conductance variations}

Monthly variations in leaf stomatal conductance and relationship between conductance and soil water content are shown in figure 7. Stomatal conductance increased and decreased during wet and dry periods irrespective of plot and species (Fig $7 \mathrm{a}$ and $\mathrm{b}$ ). There was a positive correlation between stomatal conductance and soil water content, with conductance increasing linearly with soil water content (Fig. $7 \mathrm{c}$ ).

\section{Discussion}

\section{Sap flow characteristics}

This study demonstrated diurnal patterns of sap flux density (SFD) for the tree species within the plots (Fig. 6). The results are consistent with reports for other savannas (Du et al., 2011; Butz et al., 2018). Yin et 
al., (2011) and Chen et al., (2014) demonstrated a linear relationship between SFD and VPD and revealed that the daily changes of SFD for tree species displayed single peak curves that reached maximum values between $1200 \mathrm{hrs}$ and $1400 \mathrm{hrs}$. Our results likewise uncovered positive relationships between SFD and both air temperature and VPD. Further, SFD exhibited distinct curves that reached maximum values at about $1200 \mathrm{hrs}$ and $1400 \mathrm{hrs}$. The maximum SFD values coincided with peak values of both VPD and air temperatures (Fig. 6). The results demonstrate that SFD within our plots is driven by VPD and air temperature. VPD and air temperature are known drivers of sap flow and transpiration attributable to the water potential gradient, and the ability of dry air to pull water from a source of higher water potential (Nadezhdina et al., 2019). Moreover, the correlation with VPD infers that SFD was coupled with the atmosphere with relatively low boundary layer resistance (Gomenez et al., 2019). Similar findings were reported by Deng et al., (2015) who recorded a gradual increase in tree sap flux density with increasing vapor pressure deficit up to around midday. The linear increase in SFD with VPD was linked to increased evaporative demand that was necessitated by the increased air temperature. According to the report, the peak SFD was only possible when VPD was $<1.4 \mathrm{kPa}$, beyond which stomatal conductance and transpiration drastically reduced to avoid cavitation. This is true for our experiment where sap flow density peaked when VPD was around $1.0 \mathrm{kPa}$ (Fig. $6 \mathrm{c}$ and d).

Although the dynamics of SFD were comparative in patterns, they were not synchronized. Acacia ancistroclada recorded significantly lower sap flow than the other studied species (Fig 4 and 6). This finding could show the uniqueness in habitats to which every species is adopted (Wu et al., 2017). It might also be related to the differences in the anatomical structure of the leaves of individual species. Acacia ancistroclada, which is narrow-leaved compared to the broad-leaved Comberatum molle. Under the same environmental conditions, Acacia is expected to transpire less compared to Comberatum molle due to the limited leaf area exposed to transpiration water loss. This could be the reason for the lower sap flow in Acacia observed within our plots (Fig $4 \mathrm{a}$ and b). Moreover, in response to the increasing soil water deficit and atmospheric demand following dry periods within our plots, there was a significant reduction of the transpiring leaf surface through shedding (personal observation). This could account for the decline in whole-tree sap flow in Acacia. Gomenez et al., (2019) linked lower transpiration in narrow leaved trees to lower stomatal conductance which was triggered by the accumulation of ABA in the leaves. In our study, however we did not determine the level of aba in the leaves of trees. Further, we could not determine the stomatal conductance of Acacia species due to the limitation of our equipment.

The linear relationship of SFD, with DBH, wood area and the crown projected area reported in our study (table 1) was also documented by other researchers (Kallarackal et al., 2012; Berry et al., 2017). The relationship between crown projected area and sap flow is explained by the pipe model theory (Shinozaki et al., 1964). According to the theory, the crown area and amount of leaves on a tree are supported by a proportionate of the crossectional area of the xylem vessels with equal hydraulic conductance. Consequently, the larger the crown area, the higher the transpiration and sap flow. Additionally, large projected crown areas are linked to higher leaf numbers and higher transpiration rates (Li et al., 2017). The relationship between $\mathrm{DBH}$ and sap flow is attributed to the positive relationship between $\mathrm{DBH}$ and 
sapwood area which directly transports sap flow. The report by Kallarackal et al., (2012) that large stems are linked with increased stem water storage and transport capacity agrees with the findings of our study.

\section{Sap flow responses to livestock grazing and seasonal changes in soil moisture}

Mean sap flux density was higher in the grazed plots compared to the fenced plots (Table 1). We could link this to a higher mean crown projected area in the grazed $\left(39.69 \pm 7.24 \mathrm{~m}^{2}\right)$ compared to grazed areas $\left(27.28 \pm 8.64 \mathrm{~m}^{2}\right)$. Higher crown area is linked to a grater transpiring surface and could be the reason for higher SFD (Liu et al., 2017). SFD within our plots was decoupled from soil water content at $-0.3 \mathrm{~m}$ (Fig $5 a$ and $b)$. This could be expected as tree roots within this study site are concentrated at a depth $>0.4 \mathrm{~m}$ (Fig.3). Tree sap flow within our plots followed seasonality in rainfall pattern, increasing and decreasing during wet and dry seasons respectively (Fig. $4 a$ and b). Such results were also recorded for a seasonally dry and wet forest in Thailand (Kume et al., 2007) and were linked to soil moisture stress. For our plots, however, the fluctuation in sap flow in response to seasonality in the rainfall pattern was linked to stomatal adjustment (Fig. $7 \mathrm{a}$ and b) to limits water loss during dry seasons and maintain transpiration during wet seasons. Such a phenomenon is common in isohydric tree species. However, it is inherently difficult to establish a firm relationship between sap flow and soil water content mainly because of the large spatial variation in soil properties and soil moisture, but also because of sap flow's strong dependence on other weather parameters.

\section{Conclusions}

The higher Sap flux densities in the grazed visa vie fenced plots were explained by the differences in tree cover and crown area. The savanna trees showed a uniform response to the seasonality in the rainfall pattern. They exhibited an increase and decrease in SFD following increased and reduced rainfall which coincided with wet and dry seasons respectively. This is a phenomenon that characterizes isohydric species. Acacia ancistroclada which recorded significantly lower sap flow compared to the Comberatum molle could be distinguished as best suited species for survival in Lambwe Valley under prevailing environmental change processes. The species can then be used for reforestation of the ecosystem and other similar areas. However, additional measurements need to be conducted on the eligibility of the species to confirm the conclusion.

\section{Declarations}

\section{Ethical approval and consent to participate}

Not applicable

\section{Consent for publication}

Not applicable 
Non declared

Acknowledgement: We thank the Kenya National Youth Service (NYS) Lambwe Unit for allowing us to conduct experiments on their land.

\section{Funding}

This research was funded by Kenya National Research Fund (NRF; 2016/17 FY) and International Foundation for Science (IFS) under grant number I-1-D-6174-1.

\section{Data availability statement}

The dataset used and/or analysed during the current study are available from the corresponding author on reasonable request.

\section{Authors' contribution}

All authors contributed equally to the production of the manuscript.

\section{References}

1. Avila, E., Herrera, A. and Tezara, W. 2014. Contribution of stem CO2 fixation to whole plant carbon balance in nonsucculent species. Photosynthetica, 52: 3-15.

2. Barnard, D., Meinzer, F., Lachenbruch, B., McCulloh, K., Johnson, D. and Woodruff, D. 2011. Climate related trends in sapwood biophysical properties in two conifers: avoidance of hydraulic dysfunction through coordinated adjustments in xylem efficiency, safety and capacitance. Plant Cell Environment, 34:643-654.

3. Baudena, M., D $\square$ Andrea, F. and Provenzale, A. 2010. An idealised model for tree-grass coexistence in savannas: the role of life stage structure and fire disturbances. Journal of Ecology, 98: 74-80.

4. Berry, Z., Looker, N., Holwerda, F., Aguilar, L., Colin, P., Martinez, T. and Asbjornsen, H. 2017. Why size matters: the interactive influence of tree diameter distribution and sap flow parameters on upscaled transpiration. Tree Physiology, 00: 1-13. Doi: 10.1093/treephys/tpx 124.

5. Bond, W. 2008. What limits trees in C4 grasslands and savanna? Annual Review of Ecology Evolution and Systematics, 39: 641-659.

6. Broadribb, T., Mc Adams, S., Jordan, G. and Martins, S. 2014. Conifers species adapt to low rainfall climates by following one or two divergent pathways. PNAS, 111 (40): 14489-14493.

7. Burgess. S. 2006. Measuring transpiration and response to summer precipitation in Mediterenean climate: a simple screening tool for identifying plant water-use strategies, Physiologia Plantarum, 127: 404-412.

8. Butz, P., Holscher, D., Cueva, E. and Graefe, S. 2018. Water use patterns as influenced by Phenology in a dry forest of southern Ecuador. Frontiers in Plant Science, 9: 945 doi:103389/fpls.2018.00945. 
9. Cheng, X., Zhao, W. and He, Z. 2014. Radial pattern of sap flow and response to microclimate and soil moisture in Qingai spruce (Picea crassifolia) in the upper Heihe River Basin of arid north western China. Agricultural and Forest Meteorology, 187: 14-21.

10. D Odorico, P., Caylor, K., Okin, G. and Scanlon. T. 2007. On soil moisture-vegetation feedbacks and their possible effects on dynamics of dryland ecosystems. J Geophys Res. 112:G04010.doi: 10.1029/2006JG00379.

11. DeLonge, M. and Basche, A. 2018. Managing grazing land to improve soil and promote climate change adaptation and mitigation: A global sysnthesis. Renewable Agriculture and Food Systems, 33 (3): 267-278.

12. Deng, J., Ding, G., Gao, G., Wu, B., Zhang, Y., Qin, S. and Fan, W. 2015. Sap flow dynamics and response to Hedysarum scoparium to environmental factors in semi and north western China. PLoS ONE, 10,E0131683.

13. Du, S., Wang, Y., Kume, T., Zhang, J., Otsuki, K., Yamanaka, N. and Liu, G. 2011. Sap flow characteristics and climatic responses in three forest species in the semiarid Loess Plateau region of China. Agricultural and Forest Meteorology, 151: 1-10.

14. Eliades, M., Bruggeman, A., Djuma, H. and Labcynski, M. 2018. Tree water dynamics in a semi-arid Pinus brutiaForest. Water, 10, 1039; doi: 10.3390/w10081039.

15. Gomenez, B., Jardine, K., Higuchi, N., Negron-Juarez, R., Israel de Jesus., Sampalo-Filho., Cobello, L., Fontes, C., Dawson, T., Varadharajan, C., Christianson, D., Spanner, G., Araujo, A., Warren, J., Newman, B., Holm, J., Koven, C., McDowel, N. and Chambers, J. 2019. Species-Specific Shifts in Diurnal Sap Velocity Dynamics and Hysteretic Behavior of Ecophysiological veriables during 2015-2016 ElNino Event in the Amazon Forest. Frontiers in Plant Science, 10: 830. Doi:10.3389/fpls.2019.00830.

16. Herrera, A. 2013. Response to flooding of plant water relations and leaf gas exchange in tropical tolerant trees of a black-water wetland. Frontiers in Plant Science, 4:106.doi: 10.3389/fpls.2013.00106.

17. Ilstead, U., Tobella, A., Bazie, H., Bayala, J., Verbeeten, E., Nyberg, S., Benegas, L., Murdiyarso, D., Laudon, H., Sheil, D. and Melmer, A. 2016. Intermediate tree cover can maximize ground water recharge in the seasonally dry tropics. Scientific Reports, 6:21930; DOI: 10.1038/srep21930.

18. Kallarackal, J., Otieno, D., Reineking, B., Jung, E., Schmidt, M., Granier, A. and Tenhunen, J. 2013. Functional convergence in water use of trees from different geographical regions: a meta-analysis. Trees, Doi 10.1007/s00468-012-083440.

19. Kgosikoma, E., Mojeremane, W. and Harvie, B. 2015. The impact of livestock grazing management systems on soil and vegetation characteristics across savanna ecosystems in Botswana. African Journal of Range and Forage Science, 32 (4): 271-278.

20. Kioko, J., Kiringe, J. and Seno, S. (2012). Impact of livestock grazing on savanna grassland in Kenya. Journal of Arid Land, 4 (1): 29-35.

21. Komatsu, H., Tanaka, N. and Kume, T. 2007. Do coniferous forests evaporate more water than broad leaved forest in Japan? Journal of Hydrology, 336: 361-375. 
22. Konings, A. and Gentine, P. 2017. Global variations in ecosystem- scale isohydricity. Global Change Biology, 23: 891-905.

23. Kume, T., Takizawa, H., Yoshifuji, N., Tanaka, K., Tantasirin, C., Tanaka, N. and Suzuki, M. 2007. Impact of soil drought on sap flow and water status of evergreen trees in atropical monsoon forest in northern Thailand. Forest Ecology and Management, 238: 220-230.

24. Li, Y., Krober, W., Bruelheide, H., Harldtle, W. and Goddert von Oheimb. 2017. Crown and leaf traits as predictors of subtropical tree sapling growth rate. Journal of Plant Ecology, 10(1): 136-145.

25. Liu, X., Zhao, P., Rao, X., Ma, L., Cai, X. and Zeng, X. 2008. Response of canopy stomatal conductance of Acacia mangium Forest to environmental driving factors. Front For China, 3: 64-71.

26. Maitama, J., Oslon, J., Mugatha, S., Mugisha, S. and Mutie, I. 2010. Land use changes, impacts and options for sustaining productivity and livelihoods in the basin of Lake Victoria. Journal of Sustainable Development in Africa, 12: 189-206.

27. Mapeto, T., Louw, J., Gush, M. and Pauw, J. 2018. Whole tree sap flow response to soil water and weather variables for Pinus vadiata and three indigenous species in a southern afrotemperate forest region. Southern Forest, 80 (4): 329-339.

28. McDowell, N., Pockman, W., Allen, C., Breshears, D., Cobb, N., Kolb, T., Plaut, J., Sperry, J., West, A. and William, D. 2008. Mechanisms of plant survival and mortality during drought: why do some plants survive while others succumb to drought? New Phytologist, 178: 719-739.

29. Meinzer, F., Bond, B., Warren, J. and Woodruff, D. 2005. Does water transport scale universally with tree size? Functional Ecology, 19: 558-565.

30. Miller, R., Chen, X., Robin, Y., Ma, S. and Baldocchi, D. 2010. Ground water uptake by woody vegetation in semiarid oak savanna. Water Resource Research, 46,W10501, doi:10.1029/2009WR008902.

31. Mureithi, S., Verdoodt, A., Njoka, T., Gachene, K., Warinwa, F. and Ranst, E. (2014). Impact of community conservation management on herbaceous layer and soil nutrients in a Kenyan semi-arid savannah. Land Degradation and Development, 10: 1002-1015.

32. Muriuki, G., Njoka, T., Reid, R. and Nyariki, D. (2005). Tsetse control and landuse change in Lambwe valley, south western Kenya. Agricultural Ecosystems and Environments, 106: 99-107.

33. Nadezhdina, N., Al-Okaishi, A. and Madera, P. 2019. Long-term insitu sap flow monitoring in mature Drecaena cinnabari tree on Scotra. Biologia doi.org/10.2478/s 11756-18-00185-9.

34. Njoka, T., Muriuki, G., Reid, R. and Nyariki, D. (2003). The use of sociological methods to asses land use change: a case study of Lambwe valley, Kenya. International Journal of Sociology, 7(3): 181-185.

35. O' Grady, P., Eamus, D. and Hutley, B. 1998. Transpiration increases during dry season: patterns of whole tree water use in eucalypt open-forest of northern Australia. Tree Physiology, 19: 591-597.

36. Ondier, J., Okach, D., Onyango, J. and Otieno, D. 2019. Influence of rainfall amount and livestock grazing on soil respiration in a moist Kenyan savanna. African Journal of Ecology doi: 10.1111/aje.12670.

37. Otieno, D., K'Otuto, G., Jakli, B., Maina, J., Jung, E. and Onyango, J. 2011. Spatial heterogeneity in ecosystems structure and productivity in a moist Kenyan savanna. Plant Ecology, 212: 769-789. 
38. Parolin, P. and Wittmonn, F. 2010. Struggle in the flood: Tree response to flooding stress in four tropical flood plain systems. AoB PLANTS, 2010, doi: 10.1093/aobpla/p/q003.

39. Pivovaroff, A., Pasquine, S., De Guzman, M., Alstand, K., Stemke, J. and Santiago, L. 2016. Multiple strategies for drought survival among woody plant species. Functional Ecology, doi:10.1111/13652435./2518.

40. Rodriguez-Gamir, J., Primo-Millo, E. and Forner-Giner, G. 2016. An integrated view of whole tree hydraulic architecture. Does stomatal or hydraulic conductance determine whole tree transpiration? PLoS ONE 11(5):e0155246.doi:10.1371/journal.pone.0155246.

41. Roman, D., Novick, K., Brzostek, E., Dragoni, D. and Rahman, F. 2015. The role of isohydric and anisohydric species in determining ecosystem scale response to severe drought. Oecologia, 179: 641654.

42. Ryu, Y., Baldocchi, D., Kobayashi, H., Van Ingen, C., Li, J., Black, T., Beringer, J., Van Gorsel, E., Knohl, A., Law, B. and Roupsard, O. 2011. Integration of MODIS land and atmosphere products with a coupledprocess model to estimate gross primary productivity and evapotranspiration from $1 \mathrm{~km}$ to global scale, Global Biogeochemistry, Cy.,25, GB4017,doi:10.1029/2011GB004053,2011.

43. Sankaran, M. 2019. Drought and ecological future of tropical savanna vegetation. Journal of Ecology, doi: 1111/1365-2745.13195.

44. Sankaran, M., Ratman, J. and Hannan, P. 2004. Tree-grass coexistence in savannas revisited-insights from an examination of assumptions and mechanisms invoked in existing models. Ecology Letters, 7:480-490.

45. Santiago, M., Pagay, V. and Sroock, A. 2013. Impact of electroviscosity on the hydraulic conductance of the boarded pit membrane: a theoretical investigation. Plant Phytology, 163: 999-1011.

46. Savento, S., Nikinmaa, E., Riikoner, A., Daley, M., Pettijohn, J., Mikkelsen, T., Phillips, N. and Holbrook, N. 2008. Linking xylem diameter variations with sap flow measurements. Plant Soil, 305: 77-90.

47. Scharsich, V., Otieno, D. and Bogner, C. 2019. Climbing up the hills: expansion of agriculture around ruma national park, Kenya. International Journal of Remote Sensing.

Doi.org/10.1080/01431161.2019.1591647.

48. Schmidt, M. 2007. Canopy transpiration of beech forest in north Bavaria-Structure and function in pure and mixed stands with oaks at colline and montane sites. Doctoral dissertation, University of Bayreuth, 239pp. http://opus.ub.uni-bayreuth.de/voltexte/2008/428.

49. Scholtz, R., Kiker, A., Duckworth, D., Scharler, M., Mwambi, G. and Venter, J. 2016. Different drivers create spatial vegetation cover and vertical structure in semi-arid African savannas. African Journal of Range Science, 33(2): 91-100.

50. Shinozaki, K., Yoda, K., Hozumi, K. and Kira, T. 1964. A quantitative theory of plant form-the pipe model theory, I. Basic analysis. Japan Journal of Ecology, 14: 97-104.

51. Solari, L., Johnson, S. and DeJong, T. 2006. Hydraulic conductance characteristics of peach (Prunus persica) trees on different rootstocks are related to biomass production and distribution. Tree Physiology, 26: 1343-1350. 
52. Stahl, C., Herault, B., Rossi, V., Burban, B., Brechet, C.and Bonal, D. 2013. Depth of soil water uptake by tropical forest trees during dry periods: does the dimension matters? Oecologia, 173: 1191-1201.

53. Sydack, A., Grant, C., Smit, I., Vermeulen, W., Board, J. and Zambatis, N. 2012. Climate and vegetation in semiarid savanna: development of a climate-vegetation response model linking plant metabolic performance to climate and the effect on forage availability for large herbivores. Koedoe, 54 (1): 1-12.

54. Synodino, D., Tiet, B., Lohmann, D. and Jeltsch, F. 2018. The impact of inter-annual rainfall vaiability on African savannas changes with mean rainfall. Journal of Theoretical Biology, 437: 92-100.

55. Tognetti, R., Giovannelli, A., Lavin, A., Morelli, G., Fragnito, F. and d'Andria, R. 2009. Assessing environmental controls over conductance through the soil-plant-atmosphere continuum in an experimental olive tree plantation of southern Italy. Agric. For Meteorl, 149: 1229-1243.

56. Vertessy, R., Ronyon, R., O $\square$ sullivan, S.and Gribben, P. 1995. Relationships between stem diameter, sapwood area, leaf area and transpiration in young mountain ash forest. Tree Physiology, 15: 559567.

57. William, C., Hanan, N., Neff, J., Scholes, R., Berry, J., Denning, A. and Baker, D. 2007. Africa and the global carbon cycle. Carbon Balance and Management, 2(1):3.

58. Wu, X., Tang, Y., Chen, Y., Wen, J., Xie, Y. and Lu, S. 2017. Sap flow characteristics and response to summer rainfall for Pinus tabulaeformis and Hippophae rhamnoides in the Loess hilly region of China. Ecology and Evolution, 8: 617-630.

59. Yin, X., Cheng, F. and Zhan, S. 2011. Variation of stem flow of Pinus tabuliformis and its impact factors. Journal of Northwest Forestry University, 26 (5): 24-29.

60. Yoshimwa, K., Saika, S., Yakazi, K., Ogasa, M., Shirai, M., Nakano, T., Yoshimura, M. and Ishida, A. 2016. The dynamics of carbon stored in xylem sapwood to drought-induced hydraulic stress in mature trees. Nature scientific Report, 6:24513/doi:1038/24513.

61. Zhang, S., Zhang, J. and Cao, K. 2017. Divergent hydraulic strategies in three co-occuring Anacardiaceae Tree species in a Chinese savanna. Frontiers in Plant Science, 7 : 2079.doi:10.3389/fpls.2016.02079.

\section{Figures}




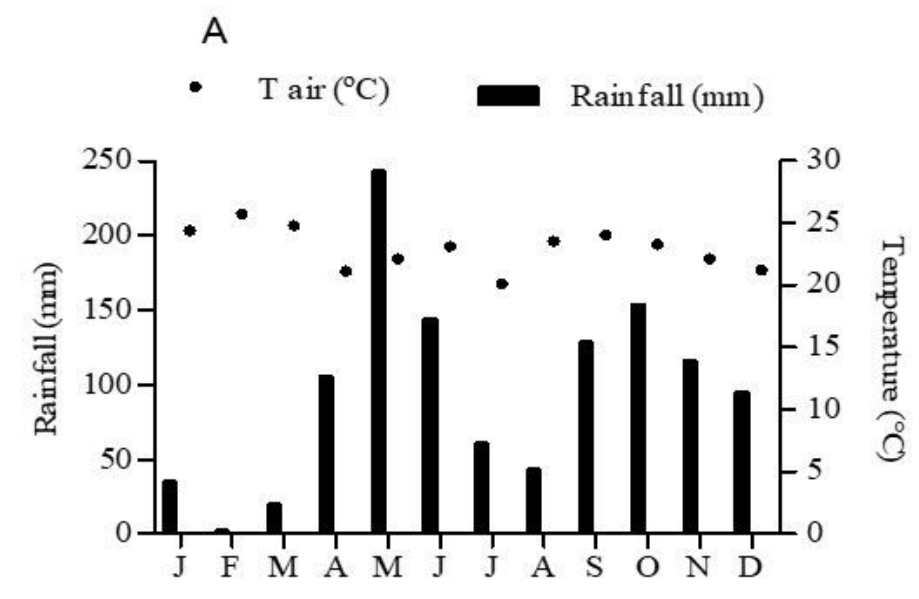

Months
B

- $\quad \mathrm{T}$ air $\left({ }^{\circ} \mathrm{C}\right) \quad \operatorname{Rainfall}(\mathrm{mm})$

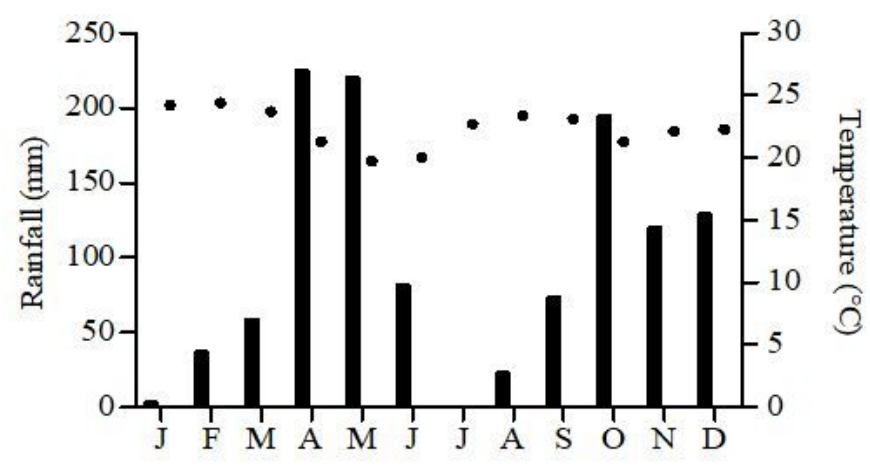

Months

Figure 1

Mean monthly air temperature (Tair) and total monthly rainfall amounts recorded in 2014 (A) and 2015 (B) respectively.
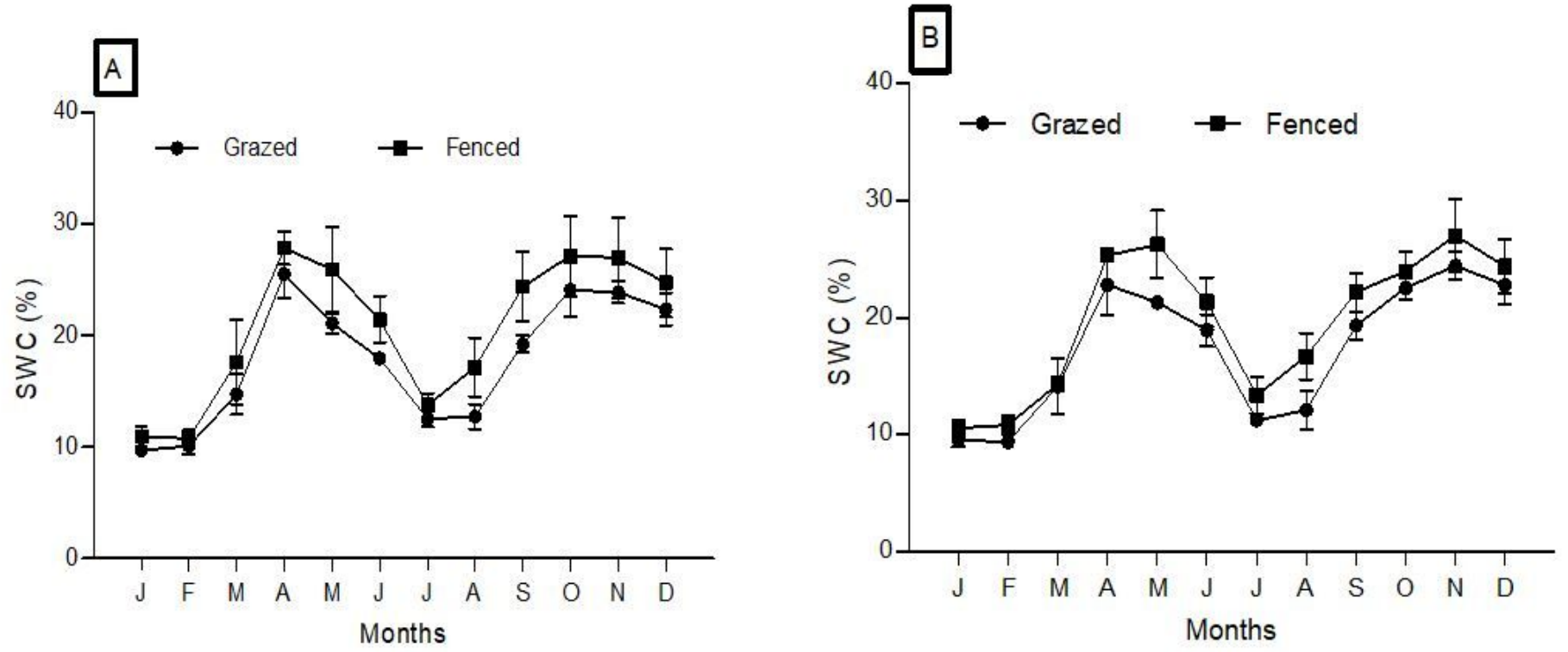

Figure 2

Mean soil water content (\%) within grazed and fenced plots measured in 2014 (A) and 2015 (B) respectively. Bars are means with \pm SD. 

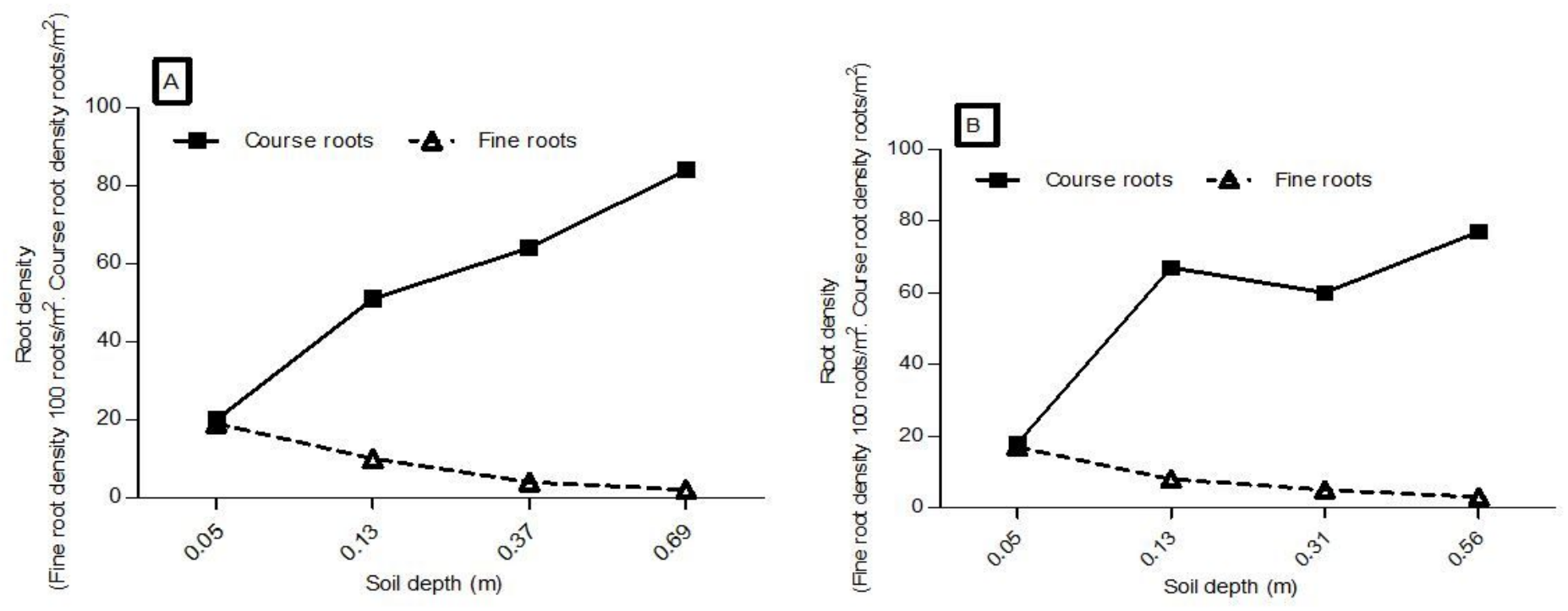

Figure 3

Root distribution in the A) locations outside the tree canopies dominated by herbaceous vegetation and B) locations under the tree canopies.
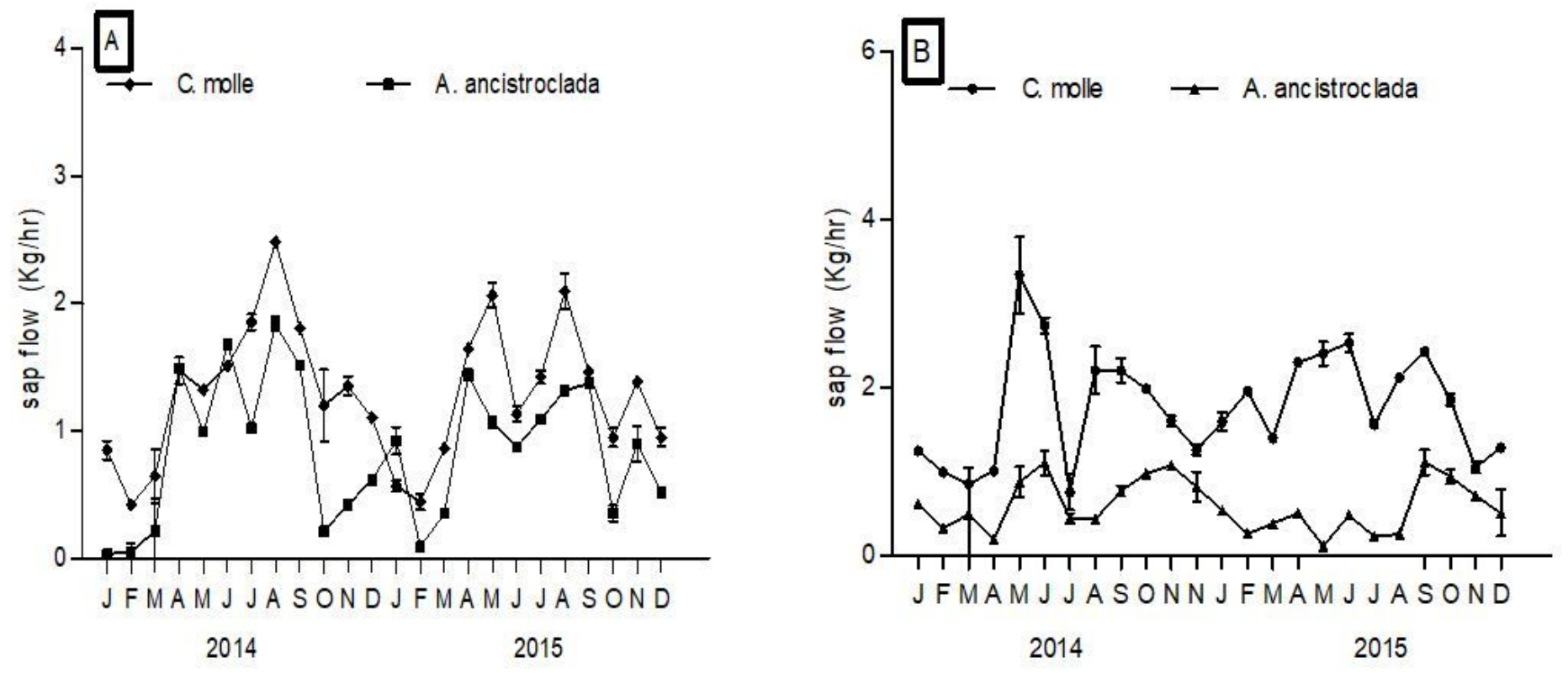

Figure 4

Monthly means of tree sap flow $(\mathrm{Kg} / \mathrm{hr})$ measured within grazed $(\mathrm{A})$ and fenced $(B)$ plots respectively. Bars are means with \pm SD. Studied trees are Comberatum molle, and Acacia ancistroclada. 

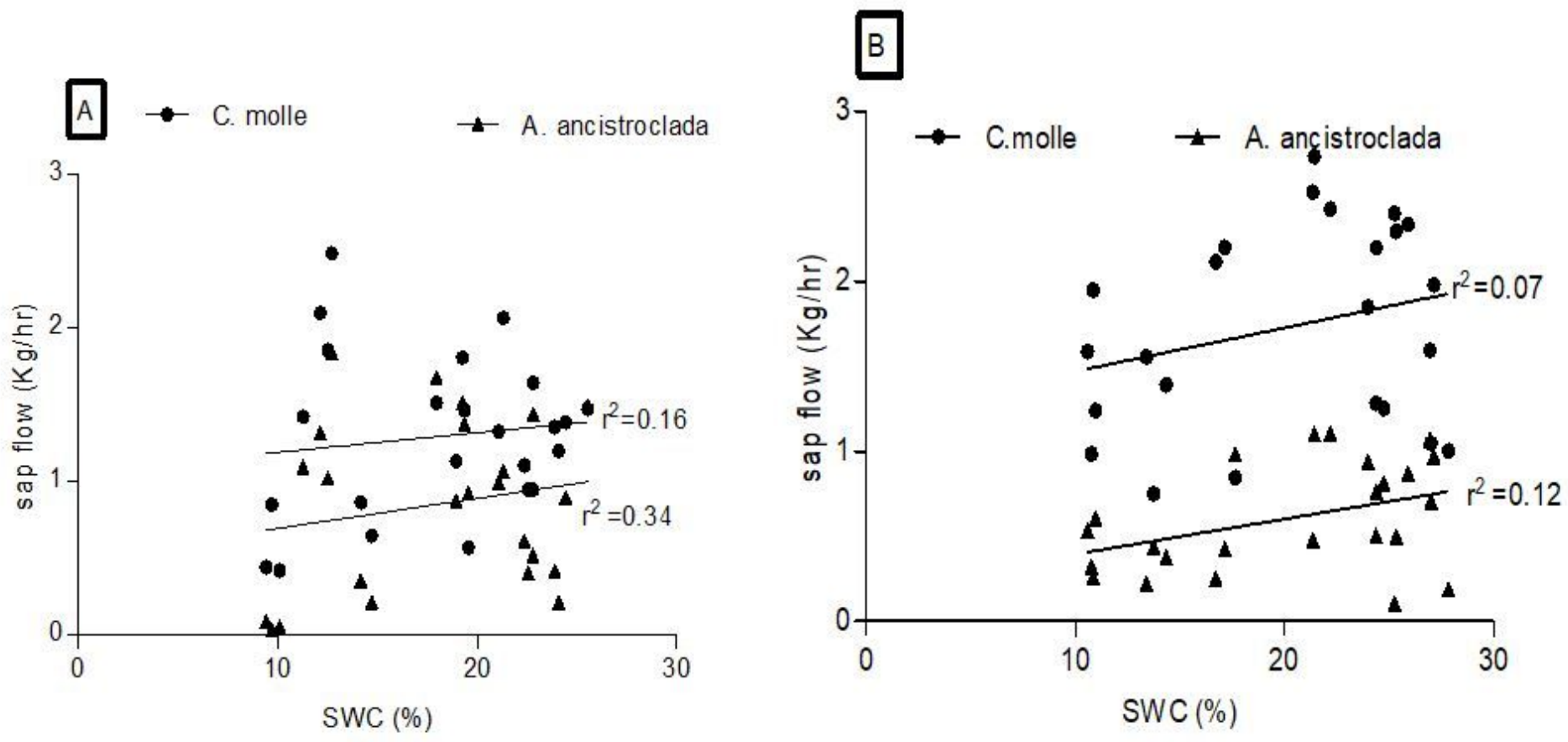

\section{Figure 5}

Relationship between sap flow and soil water content for studied trees within grazed (A) and fenced (B) plots
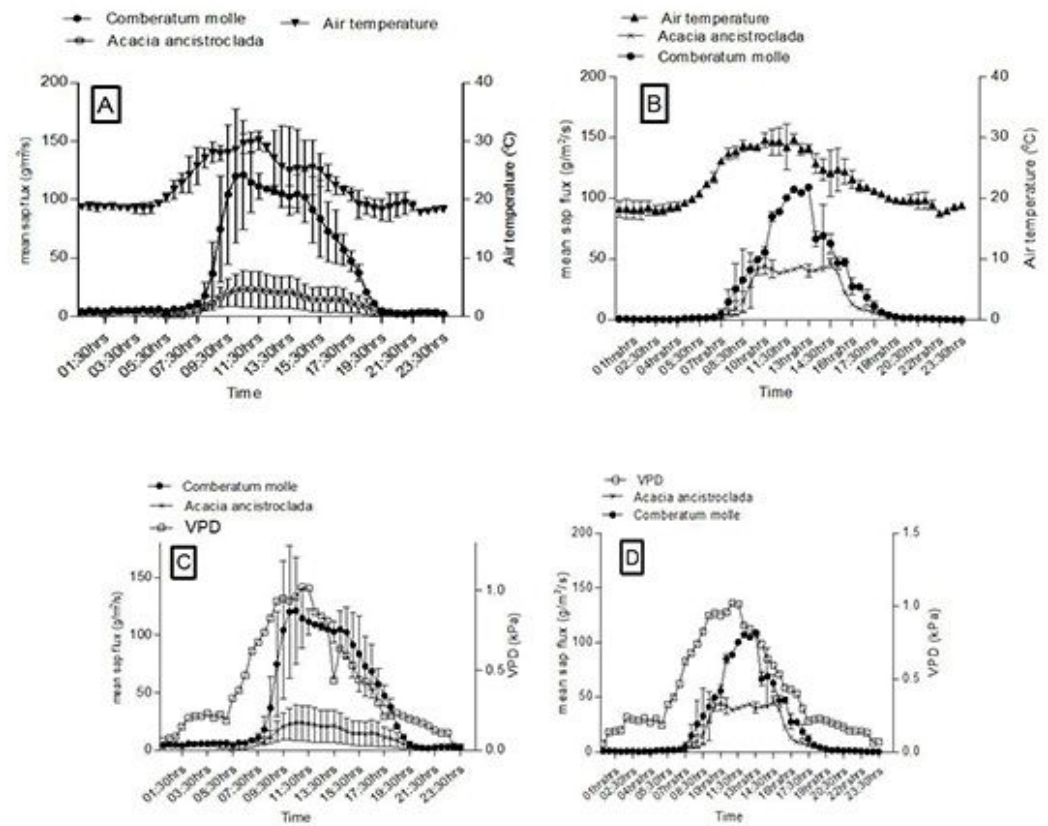

Figure 6

Diurnal course of mean sap flux density as a function of air temperature in the grazed $(A)$ and fenced plot (B) and vapor pressure deficit in grazed (C) and fenced plot (D) respectively. Data are means $\pm S D$ 

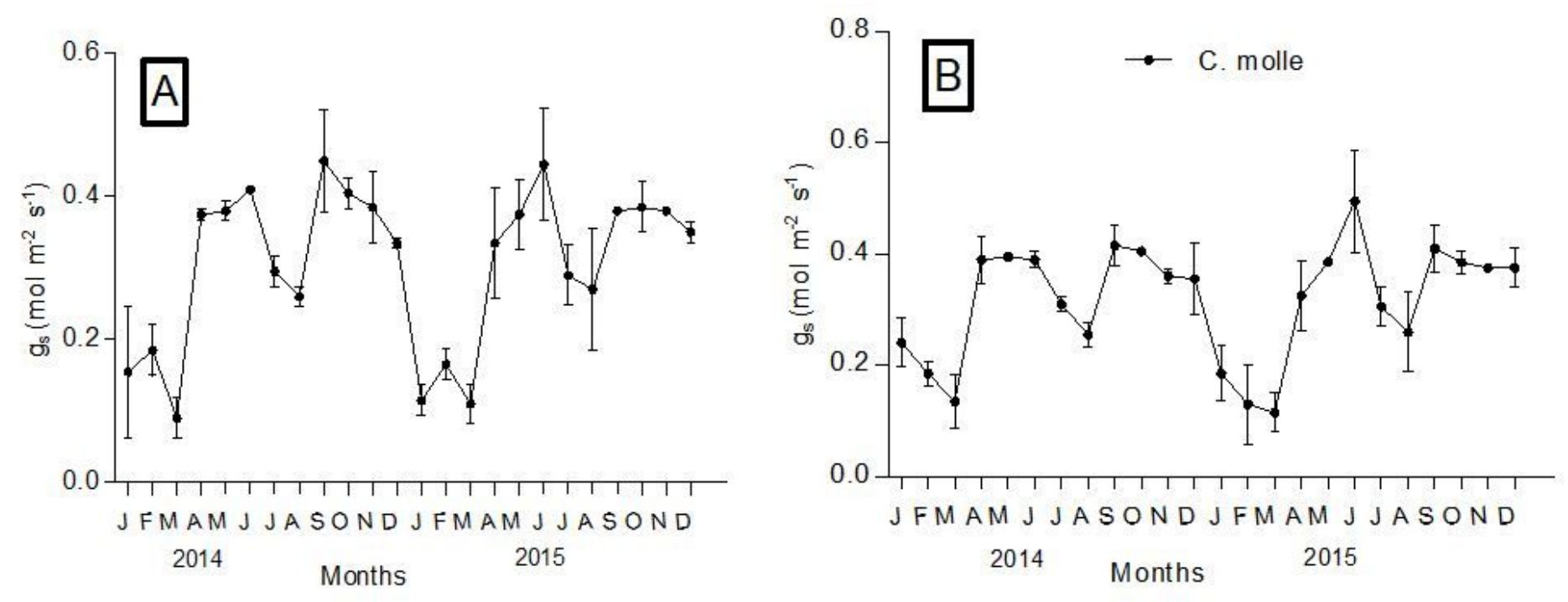

Figure 7

variations in monthly mean stomatal conductance measured within grazed (A) and fenced (B) plots. The conductance of Acacia ancistroclada was not measured because the leaves were tiny and could not fit in the cuvette of the porometer used. Error bars are \pm SD. 